NBER WORKING PAPER SERIES

\title{
CAPITAL INCOME TAXATION IN THE GLOBALIZED WORLD
}

\author{
Assaf Razin \\ Efraim Sadka \\ Working Paper 10630 \\ http://www.nber.org/papers/w10630 \\ NATIONAL BUREAU OF ECONOMIC RESEARCH \\ 1050 Massachusetts Avenue \\ Cambridge, MA 02138 \\ July 2004
}

The views expressed herein are those of the author(s) and not necessarily those of the National Bureau of Economic Research.

(C2004 by Assaf Razin and Efraim Sadka. All rights reserved. Short sections of text, not to exceed two paragraphs, may be quoted without explicit permission provided that full credit, including (C notice, is given to the source. 
Capital Income Taxation in the Globalized World

Assaf Razin and Efraim Sadka

NBER Working Paper No. 10630

July 2004

JEL No. F3, H2

\section{$\underline{\text { ABSTRACT }}$}

The behavior of taxes on capital income in the recent decades points to the notion that international tax competition that follows globalization of capital markets put strong downward pressures on the taxation of capital income; a race to the bottom. This behavior has been perhaps most pronounced in the EU-15 following the single market act of 1992. The 2004 enlargement of the EU with 10 new entrants put a strong downward pressure on capital income taxation for the EU-15 countries. Tax havens, and the inadequacy of cooperation among national tax authorities in the OECD in information exchanges, put binding ceilings on how much foreign-source capital income can be taxed. What then are the implications for the taxes on domestic-source capital income? The paper demonstrates that even if some enforcement of taxation on foreign-source capital income is feasible, a poor enforcement of international taxes would generate political processes that would reduce significantly the domestic-source capital income taxation.

Assaf Razin

Eitan Berglas School of Economics

Tel Aviv University

Tel Aviv 69978

ISRAEL

and NBER

razin@post.tau.ac.il

Efraim Sadka

Eitan Berglas School of Economics

Tel Aviv University

Tel Aviv 69978

ISRAEL 


\begin{abstract}
The behavior of taxes on capital income in the recent decades points to the notion that international tax competition that follows globalization of capital markets put strong downward pressures on the taxation of capital income; a race to the bottom. This behavior has been perhaps most pronounced in the EU-15 following the single market act of 1992. The 2004 enlargement of the EU with 10 new entrants put a strong downward pressure on capital income taxation for the EU-15 countries. Tax havens, and the inadequacy of cooperation among national tax authorities in the OECD in information exchanges, put binding ceilings on how much foreign-source capital income can be taxed. What then are the implications for the taxes on domestic-source capital income? The paper demonstrates that even if some enforcement of taxation on foreign-source capital income is feasible, a poor enforcement of international taxes would generate political processes that would reduce significantly the domestic-source capital income taxation.
\end{abstract}

\title{
1 Introduction
}

These days globalization across various economies is a universal phenomenon to reckon with. Guillermo Calvo's framework of his prolific research was, indeed, the constraints on economic policy imposed by the integrated, and fluctuating, world capital market. Maurice Obstfeld and Alan M. Taylor (2003) examine the historical development of globalization (in particular, international capital mobility) by political-economy forces. After World War I, "newly or better-enfranchised groups such as the working classes" contributed to severely impede capital mobility. The peace and prosperity that emerged following World War II, and that 
intensified after the end of the cold war, unleashed political forces for freer capital mobility. Nevetheless, the aging population (through falling birth rates and increased longevity) raises the need for tax revenues by the welfare state. This chapter focuses on capital income taxation. Can high domestic capital taxes survive international tax competition brought about by the recent widespread globalization?

Evidently, the answer is in the negative. As put succinctly by The Economist (31st May, 1997, pp. 17-23):

"Globalization is a tax problem for three reasons. First, firms have more freedom over where to locate... . This will make it harder for a country to tax [a business] much more heavily than its competitors... . Second, globalization makes it hard to decide where a company should pay tax, regardless of where it is based... . This gives them [the companies] plenty of scope to reduce tax bills by shifting operations around or by crafting transfer-pricing... . [Third], globalization... nibbles away at the edges of taxes on individuals. It is harder to tax personal income because skilled professional workers are more mobile than they were two decades ago."

Aging puts downward pressures on the welfare state when the benefits granted by it are financed by labor taxes (as demonstrated in Razin, Sadka and Swagel (2002)). Aging may, however, theoretically, boost the size of the welfare state when capital income taxation are employed to finance the benefits provided by the welfare state (see Razin, Sadka, and Swagel (2003)). If this is the case, can capital income taxation indeed rescue the welfare state with an aging population? Not necessarily, if strong international tax competition in the era of globalization imposes severe constraints on capital income taxation, and thereby put into question its standing in the public finance of the welfare state. 
We develop in this Chapter a political economy model to assess how the forces of globalization affect the taxation of capital income.

The Chapter is organized as follows. Section 2 provides a simple analytical framework for the study of capital taxation in the presence of international capital mobility. In particular, we analyze in this section the tax structure in the political-economy equilibrium. In section 3 we apply the model for the analysis of international tax competition. Section 4 concludes.

\section{International Capital Mobility: A Stylized Political- Economy Tax Model}

We present a stripped-down model of international capital mobility, which enables us to explore key issues of international taxation, without being sidetracked by irrelevant complications. We consider an economy that lives for two periods, indexed by $t=1,2$. There is one aggregate, all-purpose good in each period, serving for both consumption and investment.

\subsection{Households}

There are two types of workers: Skilled workers, who have high productivity, and provide one efficiency unit of labor per unit of labor time, and unskilled workers, who provide $q<1$ efficiency units of labor per unit of time. Workers have one unit of labor time during each one of the two periods of their life. They are born without skills and thus with low productivity. In the first period, each worker chooses whether to get an education and become a skilled worker, or instead remain unskilled. 
There is a continuum of individuals, characterized by an innate ability parameter, $e$, which is the time needed to acquire a skill. By investing $e$ units of labor time in education, in the first period, a worker becomes skilled; after which the remaining $(1-e)$ units of labor time in the first period provide an equal amount of efficiency units of labor in the balance of the first period. We assume that the individual also provides one efficiency unit of labor in the second period. We also assume a positive pecuniary cost of acquiring skills, $\gamma$, which is not tax deductible.

Given these assumptions, there exists, again, a cutoff level, $e^{*}$, such that those with education cost parameters below $e^{*}$ will invest in education and become skilled, whereas everyone else remains unskilled. The cutoff level is determined by the equality between the present value of the payoff to education and the cost of education (including foregone income):

$$
\left(1-\tau_{L}\right)(1-q)\left[w_{1}+\frac{w_{2}}{1+\left(1-\tau_{D}\right) r}\right]=\left(1-\tau_{L}\right) w_{1} e^{*}+\gamma
$$

where $w_{t}$ is the wage rate per efficiency unit of labor in period $t=1,2 ; r$ is the domestic rate of interest; $\tau_{L}$ is the tax rate on labor income (constant over time); and $\tau_{D}$ is the tax rate on capital income of residents from domestic sources (see below). Rearranging terms, equation (1) yields:

$$
e^{*}=(1-q)\left[1+\frac{w_{2} / w_{1}}{1+\left(1-\tau_{D}\right) r}\right]-\frac{\gamma}{\left(1-\tau_{L}\right) w_{1}} .
$$

Note that the two taxes, the tax on labor income and the tax on capital income, have opposite effects on the decision to acquire skill. The tax on labor income reduces the foregone (net of tax) income component of the cost of education. It also reduces the payoff to education by the same proportion. ${ }^{1}$ Were the pecuniary cost $\gamma$ equal to zero (or else tax-deductable), the labor income tax would have no effect on the decision to acquire 
skill. However, with a positive pecuniary cost of education, the labor income tax has a negative effect on acquiring skills: It reduces $e^{*}$ and, consequently, also the proportion of the population who becomes skilled [namely, $G\left(e^{*}\right)$ ]. On the other hand, the tax on capital income has a positive effect on education, because it reduces the (net-of-tax) discount rate; thereby raising the present value of the future payoff to education.

We assume for the sake of simplicity that the individual's leisure time is exogenously given. Nevertheless, total labor supply is distorted by the taxes, as can be seen from equation (2). Note that there are $G\left(e^{*}\right)$ skilled individuals and $1-G\left(e^{*}\right)$ unskilled individuals in each period. The labor supply of each one of the unskilled individuals, in efficiency units, is $q$, in each period. Therefore, total labor supply in efficiency units of the unskilled individuals is $q\left[1-G\left(e^{*}\right)\right]$ in each period. However, a skilled individual devotes $e$ units of her time in the first period to acquire education, and hence works only $1-e$ units of time in the first period. Thus, the individual labor supply in the first period varies over $e$. The labor supply of skilled individuals is equal to $\int_{0}^{e^{*}}(1-e) d G$. Any skilled individual supplies as labor all of her unit time in the second period. Thus, total labor supply $\left(L_{t}\right)$ in efficiency units in period $t=1,2$, is given by:

$$
L_{1}=\int_{0}^{e^{*}}(1-e) d G+q\left[1-G\left(e^{*}\right)\right]
$$

and

$$
L_{2}=G\left(e^{*}\right)+q\left[1-G\left(e^{*}\right)\right]
$$

For the sake of simplicity, assume that all individuals have identical preferences over first and second-period consumption $\left[c_{1}(e)\right.$ and $c_{2}(e)$, respectively], represented by a common, concave utility function $u\left[c_{1}(e), c_{2}(e)\right]$. Each individual has initial income (endowment) in the first period of $I_{1}$ units of the consumption-capital good. The total amount of the initial 
endowment $\left(I_{1}\right.$, because the size of the population is normalized to one) serves as the stock of capital employed in the first period. (This initial endowment is generated by past savings or is inherited.) Because taxation of the fixed initial endowment is not distortionary, we may assume that the government could efficiently tax away the entire value of the initial endowments. Thus, an individual of type $e$ faces the following budget constraints in periods one and two, respectively:

$$
c_{1}(e)+s_{D}(e)+s_{F}(e)=E_{1}(e)+T_{1}
$$

and

$$
\begin{aligned}
c_{2}(e)= & T_{2}+E_{2}(e)+s_{D}(e)\left[1+\left(1-\tau_{D}\right) r\right] \\
& +s_{F}(e)\left[1+\left(1-\tau_{F}-\tau_{N}^{*}\right) r^{*}\right]
\end{aligned}
$$

where $E_{t}(e)$ is after-tax labor income, net of the cost of education, $t=1,2$, and where $T_{t}$ is a uniform lump-sum transfer (demogrant) in period $t=1,2$. That is:

$$
E_{1}(e)=\left\{\begin{array}{cc}
\left(1-\tau_{L}\right)(1-e) w_{1}-\gamma & \text { for } e \leqq e^{*} \\
\left(1-\tau_{L}\right) q w_{1} & \text { for } e \geqq e^{*}
\end{array}\right.
$$

and

$$
E_{2}(e)=\left\{\begin{array}{cl}
\left(1-\tau_{L}\right) w_{2} & \text { for } e \leqq e^{*} \\
\left(1-\tau_{L}\right) q w_{2} & \text { for } e \geqq e^{*}
\end{array} .\right.
$$

An individual can channel savings to either the domestic or foreign capital market, because the economy is open to international capital flows. We denote by $s_{D}(e)$ and $s_{F}(e)$ savings channelled by an $e$-individual to the domestic and foreign capital market, respectively. We denote by $r$ and $r^{*}$ the real rate of return in these markets, respectively. ${ }^{2}$ The 
government levies a tax at the rate $\tau_{D}$ on capital (interest) income from domestic sources. Capital (interest) income from foreign sources is subject to a non-resident tax at the rate of $\tau_{N}^{*}$, levied by the foreign government. The domestic government may levy an additional tax on its domestic residents, on their foreign-source income at an effective rate of $\tau_{F}$. Note that $\tau_{F}+\tau_{N}^{*}$ is the effective tax rate on foreign-source income of residents.

For the sake of brevity, we consider only the case of a capital-exporting country that is, its national savings exceed domestic investment, with the difference (defined as the current account surplus) invested abroad. ${ }^{3}$ (The analogous case of a capital-importing country can be worked out similarly.) By arbitrage possibilities, the net-of-tax rate of interest, earned at home and abroad, are equalized; that is:

$$
\left(1-\tau_{D}\right) r=\left(1-\tau_{F}-\tau_{N}^{*}\right) r^{*}
$$

Employing (9), one can consolidate the two one-period budget constraints (5) and (6) into one life-time budget constraint:

$$
c_{1}(e)+R c_{2}(e)=E_{1}(e)+R E_{2}(e)+T,
$$

where

$$
R=\left[1+\left(1-\tau_{D}\right) r\right]^{-1},
$$

is the net-of-tax discount factor (which is also the relative after-tax price of second-price consumption), and

$$
T \equiv T_{1}+R T_{2}
$$

is the discounted sum of the two transfers $\left(T_{1}\right.$ and $\left.T_{2}\right) .{ }^{4}$ 
As usual, the consumer maximizes her utility function, subject to her lifetime budget constraint. A familiar first-order condition for this optimization is that the intertemporal marginal rate of substitution is equated to the tax-adjusted interest factor:

$$
\operatorname{MRS}(e) \equiv u_{1}\left[c_{1}(e), c_{2}(e)\right] / u_{2}\left[c_{1}(e), c_{2}(e)\right]=1+\left(1-\tau_{D}\right) r=R^{-1}
$$

where $u_{i}$ denotes the partial-derivative of $u$ with respect to its ith argument, $i=1,2$. Equations (13) and (10) yield the consumption-demand functions $\bar{c}_{1}\left[R, E_{1}(e)+R E_{2}(e)+T\right]$ and $\bar{c}_{2}\left[R, E_{1}(c)+R E_{2}(e)+T\right]$ of an $e$-individual. The maximized value of the utility function of an $e$-individual, $v\left[\mathrm{R}, E_{1}(e)+R E_{2}(e)+T\right]$, is the familiar indirect utility function.

Denote the aggregate consumption demand, in period $t=1,2$, by:

$$
\begin{aligned}
& C_{t}\left[R,\left(1-\tau_{L}\right) w_{1},\left(1-\tau_{L}\right) w_{2}, T\right] \equiv \int_{0}^{1} \bar{c}_{t}\left[R, E_{1}(e)+R E_{2}(e)+T\right] d G= \\
& \int_{0}^{e^{*}} \bar{c}_{t}\left[R,\left(1-\tau_{L}\right)(1-e) w_{1}+R\left(1-\tau_{L}\right) w_{2}+T-\gamma\right] d G+ \\
& {\left[1-G\left(e^{*}\right)\right] \bar{c}_{t}\left[R,\left(1-\tau_{L}\right) q w_{1}+R\left(1-\tau_{L}\right) q w_{2}+T\right],}
\end{aligned}
$$

where use is made of equations (7) and (8). Note that $e^{*}$ is a function of $\left(1-\tau_{L}\right) w_{1}$ and of $R w_{2} / w_{1}$ [see equation (2)].

\section{$2.2 \quad$ Producers}

All firms are identical and possess constant-returns-to-scale technologies, so that with no further loss of generality we assume that there is only one firm, which behaves competitively. Its objective, dictated by the firm's shareholders, is to maximize the discounted sum of the cash flows accruing to the firm. We assume that the firm finances its investment by issuing debt. In the first period, it has a cash flow of $\left(1-\tau_{D}\right)\left[F\left(K_{1}, L_{1}\right)-w_{1} L_{1}\right]-\left[K_{2}-(1-\right.$ 
$\left.\delta) K_{1}\right]+\tau_{D} \delta K_{1}$, where $F(\cdot)$ is a neo-classical, constant-returns-to-scale, production function. In the second period, the firm has an operating cash flow of $\left(1-\tau_{D}\right)\left[F\left(K_{2}, L_{2}\right)-w_{L} L_{2}\right]+$ $(1-\delta) K_{2}+\tau_{D} \delta K_{2}$. We denote by $\delta$ both the physical and the economic rate of depreciation (assumed for the sake of simplicity to be equal to each other). This depreciation rate is also assumed to apply for tax purposes. We essentially assume that the corporate income tax is fully integrated into the individual income tax. With such integration of the individual income tax and the corporate tax, there is no difference between debt and equity finance. Specifically, we assume that the individual is assessed a tax (at the rate $\tau_{D}$ ) on the profits of the firm, whether or not they are distributed, and that there is no tax at the firm level. The firm's discounted sum of its after-tax cash flow is therefore:

$$
\begin{aligned}
\pi= & \left(1-\tau_{D}\right)\left[F\left(K_{1}, L_{1}\right)-w_{1} L_{1}\right]-\left[K_{2}-(1-\delta) K_{1}\right]+\tau_{D} \delta K_{1} \\
& +\left\{\left(1-\tau_{D}\right)\left[F\left(K_{2}, L_{2}\right)-w_{2} L_{2}\right]+\tau_{D} \delta K_{2}+(1-\delta) K_{2}\right\} /\left[1+\left(1-\tau_{D}\right) r\right]
\end{aligned}
$$

Note that $K_{1}$ is the pre-existing stock of capital at the firm, carried over from period zero. Maximizing (15) with respect to $K_{2}, L_{1}$ and $L_{2}$ yields the standard marginal productivity conditions:

$$
\begin{aligned}
& F_{L}\left(K_{1}, L_{1}\right)=w_{1}, \\
& F_{L}\left(K_{2}, L_{2}\right)=w_{2},
\end{aligned}
$$

and

$$
F_{K}\left(K_{2}, L_{2}\right)-\delta=r
$$

Note that although taxes do not affect the investment rule of the firm, nevertheless, the taxes are distortionary. To see this distortion, consider the intertemporal marginal 
rate of transformation $(M R T)$ of second-period consumption (namely, $c_{2}$ ) for first-period consumption (namely, $c_{1}$ ). It is equal to $(1-\delta)+F_{K}\left(K_{2}, L_{2}\right)$ : When the economy gives up one unit of first-period consumption in order to invest it, then it receives in the second period the depreciated value of this unit (namely, $1-\delta$ ), plus the marginal product of capital (namely, $F_{K}$ ). From equation (18), we can see that:

$$
M R T=1+r
$$

However, from equation (13) we can see that the common intertemporal marginal rate of substitution of all individuals is equal to:

$$
M R S=1+\left(1-\tau_{D}\right) r
$$

Hence, the $M R T$ need not equal the $M R S$; in fact, the MRT is larger than the MRS when the tax rate on capital income from domestic sources $\left(\tau_{D}\right)$ is positive. This violates one of the Pareto-efficiency conditions.

Note that the firm has pure profits (or surpluses) stemming from the pre-existing stock of capital, $K_{1}$. We denote this surplus by $\pi_{1}$, which is equal to:

$$
\pi_{1}=\left(1-\tau_{D}\right)\left[F\left(K_{1}, L_{1}\right)-\delta K_{1}-w_{1} L_{1}\right]+K_{1} .
$$

The surplus consists of the after-tax profit of the first period, plus the level of the pre-existing stock of capital. Given the constant-returns-to-scale technology, the firm's after-tax cash flow consists entirely of this surplus, that is $\pi=\pi_{1}$. This equality follows by substituting the Euler's equation, $F\left(K_{2}, L_{2}\right)=F_{K}\left(K_{2}, L_{2}\right) K_{2}+F_{L}\left(K_{2}, L_{2}\right) L_{2}$, and the marginal productivity conditions, equations (17) and (18), into equation (15). Naturally, the government fully taxes away the surplus $\pi_{1}$, before resorting to distortionary taxation (via the various $\tau^{\prime} s$ ). 


\subsection{Policy Tools: Taxes, Transfers and Debt}

The government has a consumption demand of $C_{t}^{G}$ in period $t=1,2$. We assume that the government can lend or borrow at market rates. With no loss of generality, we assume that the government operates only in the foreign capital market, that is, its first-period budget surplus is invested abroad; for concreteness, suppose that this is positive. Therefore, the government does not have to balance its budget period by period, but only over the two-period horizon:

$$
\begin{aligned}
& C_{1}^{G}+R^{*} C_{2}^{G}+T_{1}+R^{*} T_{2}= \\
& \tau_{L} w_{1} L_{1}+\tau_{L} R^{*} w_{2} L_{2}+\tau_{D} R^{*} r S_{D}+\tau_{F} R^{*} r^{*} S_{F} \\
& +\pi_{1}+\tau_{D}\left[F\left(K_{1}, L_{1}\right)-\delta K_{1}-w_{1} L_{1}\right],
\end{aligned}
$$

where:

$$
S_{D}=\int_{0}^{1} s_{D}(e) d G
$$

is the aggregate private savings, channelled into the domestic capital market;

$$
S_{F}=\int_{0}^{1} s_{F}(e) d G
$$

is the foreign aggregate private savings, channelled into the foreign capital market; and

$$
R^{*}=\left[1+\left(1-\tau_{N}^{*}\right) r^{*}\right]^{-1}
$$


is the foreign discount rate faced by the domestic economy. Note that the foreign government levies a tax at the rate $\tau_{N}^{*}$ on interest income from the home government budget surplus invested abroad.

The left hand side of equation (20) represents the present value of the government expenditures on public consumption and transfers, discounted by the factor $R^{*}$, which is the interest factor at which the domestic economy can lend. The right-hand side of equation (20) represents the present value of the revenues from the labor income taxes, the interest income taxes, and the pure surplus of the firm.

Market clearance in the first period requires that:

$$
C A+C_{1}+C_{1}^{G}+K_{2}-(1-\delta) K_{1}+G\left(e^{*}\right) \gamma=F\left(K_{1}, L_{1}\right)
$$

where $C A$ is the current account surplus. ${ }^{5}$ Market clearance in the second period requires that:

$$
C_{2}+C_{2}^{G}=F\left(K_{2}, L_{2}\right)+(1-\delta) K_{2}+C A\left[1+\left(1-\tau_{N}^{*}\right) r^{*}\right]
$$

Note that the tax at the rate $\tau_{N}^{*}$ is levied by the foreign country on the interest income of the residents of the home country, and must therefore be subtracted from the resources available to the home country.

In order to get one present-value resource constraint, we can substitute the current account surplus, $C A$, from equation (24) into equation (25)

$$
\begin{aligned}
& C_{1}+R^{*} C_{2}+C_{1}^{G}+R^{*} C_{2}^{G}+K_{2}-(1-\delta) K_{1}+ \\
& G\left(e^{*}\right) \gamma=F\left(K_{1}, L_{1}\right)+R^{*} F\left(K_{2}, L_{2}\right)+R^{*}(1-\delta) K_{2} .
\end{aligned}
$$




\section{$2.4 \quad$ Median Voter Equilibrium}

In this model, $e$ is the only characteristic that distinguishes one individual from another. Recall that the lower is $e$, the more able is the individual and more objectionable she is for tax hikes. We therefore take the median voter to be the decisive voter. Therefore, the political-economy equilibrium tax rates maximize the (indirect) utility of the median voter. Policy tools at the government's disposal are inter alia labor income taxes and capital income taxes. The derivation of the equilibrium is relegated to the appendix.

The equilibrium tax on capital income is implicitly given by the following condition

$$
1-\delta+F_{K}\left(K_{2}, L_{2}\right)=1+\left(1-\tau_{N}^{*}\right) r^{*}
$$

The political economy equilibrium stock of capital [implicitly determined from equation (27) ascertains the aggregate production efficiency theorem (Diamond and Mirrlees (1971)): The intertemporal marginal rate of transformation [which is $1-\delta+F_{K}\left(K_{2}, L_{2}\right)$ ] must be equated to the world intertemporal marginal rate of transformation faced by the domestic economy [which is equal to $1+\left(1-\tau_{N}^{*}\right) r^{*}$ ].

This rule can be seen in Figure 1, where first-period total (private and public) consumption $\left(C_{1}+C_{1}^{G}\right)$ is plotted on the horizontal axis and second-period total consumption $\left(C_{2}+C_{2}^{G}\right)$ on the vertical axis. Suppose that $L_{1}, L_{2}$ and $e^{*}$ were already set at their political-economy equilibrium levels. The production possibility frontier is described by the curve $A B D$ whose slope is equal (in absolute value) to $(1-\delta)+F_{K}\left(K_{2}, L_{2}\right)$. The political equilibrium stock of $K_{2}$ is $H D$, which gives rise to the consumption possibility frontier given by $M B N$. Any other level of $K_{2}$, say $H^{\prime} D$, must generate a lower consumption possibility frontier - the curve $M^{\prime} B^{\prime} N^{\prime}$.

Employing the firm's investment rule [the marginal productivity condition (18)] and the arbitrage condition [equation (9)], we can conclude from equation (27) that: 


$$
r=\left(1-\tau_{N}^{*}\right) r^{*}
$$

That is, the pre-tax domestic rate of interest $(r)$ must be equated to world rate of interest faced by the domestic economy, which is the world rate of interest, net of the source taxes. Equations (9) and (28) yield the political-economy equilibrium tax on foreign-source income:

$$
\tau_{F}=\tau_{D}\left(1-\tau_{N}^{*}\right)
$$

Thus, in the political-economy equilibrium, the home country imposes the same tax rate $\left(\tau_{D}\right)$ on foreign-source income from capital as on domestic-source income from capital, except that a deduction is allowed for foreign taxes paid (and levied at source): One dollar earned abroad is subject to a tax at source at the rate $\tau_{N}^{*}$; the after-foreign-tax income, which is $1-\tau_{N}^{*}$, is then taxed by the home country at the rate $\tau_{D}$. The total effective tax rate paid on foreign-source income is therefore:

$$
\tau_{F}+\tau_{N}^{*}=\tau_{D}+\tau_{N}^{*}-\tau_{N}^{*} \tau_{D}
$$

\section{International Tax Competition and Capital Taxation}

A critical issue of taxation, in the era of the globalization of the capital markets, is the ability, or the inability, of national governments to tax their residents on foreign-source capital income. An editorial in the New York Times (May 26th, 2001) underscores the severity of this issue:

"From Antigua in the Caribbean to Nauru in the South Pacific, offshore tax havens leach billions of dollars every year in tax revenues from countries around the world... . The Internal Revenue Service estimates that Caribbean tax havens 
alone drain away at least $\$ 70$ billion per annum in personal income tax revenue. The OECD suspects the total worldwide to be in the hundreds of billions of dollars... the most notorious tax havens do not even extend their minimal tax rates to their own citizens or domestic enterprises. Their primary aim is to encourage and profit from individuals and businesses seeking to evade taxes in their own countries."

It is fairly safe to argue that tax havens, and the inadequacy of cooperation among national tax authorities in the OECD in information exchanges, put binding ceilings on how much foreign-source capital income can be taxed. What then are the implications for the taxes on domestic-source capital income?

Consider the extreme situation where the home country cannot effectively enforce any tax on foreign-source capital income of its residents. That is, suppose that $\tau_{F}=0$. Then we can see from the political-equilibrium tax rule applying to foreign-source capital income, equation (29), that the tax rate on domestic-source capital income, $\tau_{D}$, would be set to zero too. Thus, the capital income tax vanishes altogether. And even if some enforcement of taxation on foreign-source capital income is feasible so that $\tau_{F}$ does not vanish altogether, it still follows from equation (29) that $\tau_{D}=\tau_{F} /\left(1-\tau_{N}^{*}\right)$; so that a low $\tau_{F}$ generates a low $\tau_{D}$. Indeed, a poor enforcement of international taxes would generate political processes that would reduce significantly the domestic-source capital income taxation.

The unwillingness of foreign tax authorities to cooperate with the home tax authority in helping to enforce capital taxation on the capital income of residents of the home country originating abroad usually stems from their desire to lure capital to their countries. This is what is meant by tax competition. They further compete with the home country by lowering the source $\operatorname{tax}\left(\tau_{N}^{*}\right)$ they levy on the capital income of the residents of the home country. We thus capture formally the effect of tax competition by assuming that $\tau_{N}^{*}$ falls, as foreign 
governments lure capital to their countries. Then we can see from equation (28) that $r$, the net (of depreciation $\delta$ ) marginal product of domestic capital, must rise. With diminishing marginal product, this must happen when the stock of domestic capital falls and more capital flows abroad. Hence, the tax base for the domestic-source capital income shrinks, thereby turning the enforcement of foreign-source capital income all the more acute.

\section{Conclusion}

The behavior of taxes on capital income in the recent decades points to the notion that international tax competition that follows globalization of capital markets put strong downward pressures on the taxation of capital income; a race to the bottom. This behavior has been perhaps most pronounced in the EU-15 following the single market act of 1992. [See, for

example, Razin and Sadka (forthcoming)]. The 2004 enlargement of the EU with 10 new entrants put a strong downward pressure on capital income taxation for the EU-15 countries. Table 1 describes the corporate tax tates in the 25 EU countries in 2004. It reveals a marked gap between the original EU-15 countries and the 10 accession countries. The latter have significantly lower rates. Estonia, for instance, has no corporate tax; the rates in Cyprus and Lithuania are 15\%; and 19\% in Latvia, Poland and Slovakia. In sharp contrast, the rates in Belgium, France, Germany, Greece and Italy and the Netherlands range from $33 \%$ to $40 \%$. Eurpe's new constitution, adopted by the European Summit in Brussels, June 19, 2004 (the text, however, has yet to be ratified in all 25 member states), cannot stop the tax competition process because the new constitution retains the national veto in tax cooperation, and harmonization. But, there is a flexibility for some countries which want to push ahead tax harmonization, to do so. Indeed, Germany and France are currently pushing some of the new entrants to raise their corporate tax rates. Tax competition within the EU is in sharp contrast to the US federal fiscal system, where the capital income tax (on individuals 
and corporations) is federal and not state specific. But both the EU and the US are subject to severe tax competition from the rest of the world.

\section{Appendix: Derivation of the Political-Economy Equi- librium}

The political-economy equilibrium tax rates maximize the (indirect) utility of the median voter. Denoting the indirect utility function of the median voter by $V$, it is given by:

$$
V\left(e_{M}, R, w_{1}^{N}, w_{2}^{N}, T\right)=\left\{\begin{array}{c}
v\left[R,\left(1-e_{M}\right) w_{1}^{N}+R w_{2}^{N}+T-\gamma\right] \text { if } e_{M}<e^{*} \\
v\left[R, q\left(w_{1}^{N}+R w_{2}^{N}\right)+T\right] \text { if } e_{M}>e^{*}
\end{array}\right.
$$

where $w_{t}^{N}=\left(1-\tau_{L}\right) w_{t}$ is the after-tax wage per efficiency unit of labor in period $t=1,2$.

Policy tools at the government's disposal are inter alia labor income taxes and capital income taxes. We therefore assume that the government can effectively choose the after-tax wage rates $\left(w_{1}^{N}\right.$ and $\left.w_{2}^{N}\right)$ and the after-tax discount factor $(R)$. The government can choose also $T$, the discounted sum of the lump-sum transfers $\left(T_{1}\right.$ and $\left.T_{2}\right)$. Once $w_{1}^{N}, w_{2}^{N}, R$ and $T$ are chosen, then private consumption demands $\left[C_{1}\left(R, w_{1}^{N}, w_{2}^{N}, T\right)\right.$ and $\left.C_{2}\left(R, w_{1}^{N}, w_{2}^{N}, T\right)\right]$ are determined. The cutoff level, $e^{*}$, and labor supplies, $L_{1}$ and $L_{2}$, are also determined as follows:

$$
\begin{gathered}
e^{*}\left(R, w_{1}^{N}, w_{2}^{N}\right)=(1-q)\left[1+R w_{2}^{N} / w_{1}^{N}\right]-\gamma / w_{1}^{N}, \\
L_{1}\left(R, w_{1}^{N}, w_{2}^{N}\right)=\int_{0}^{e^{*}\left(R, w_{1}^{N}, w_{2}^{N}\right)}(1-e) d G+q\left\{1-G\left[e^{*}\left(q, w_{1}^{N}, w_{2}^{N}\right]\right\},\right.
\end{gathered}
$$

and 


$$
L_{2}\left(R, w_{1}^{N}, w_{2}^{N}\right)=G\left[e^{*}\left(R, w_{1}^{N}, w_{2}^{N}\right)\right]+q\left\{1-G\left[e^{*}\left(R, w_{1}^{N}, w_{2}^{N}\right)\right]\right\} .
$$

In choosing its policy tools $\left(R, w_{1}^{N}, w_{2}^{N}\right.$, and $\left.T\right)$ and its public-consumption demands $\left(C_{1}^{G}\right.$ and $\left.C_{2}^{G}\right)$, the government is constrained by the economy-wide "budget" constraint (26), where $C_{1}, C_{2}, L_{1}, L_{2}$ and $e^{*}$ are replaced by the functions $C_{1}(\cdot), C_{2}(\cdot), L_{1}(\cdot), L_{2}(\cdot)$ and $e^{*}(\cdot)$, given by equations $(14)$ and $\left(2^{\prime}\right)-\left(4^{\prime}\right)$, respectively. Note that the capital stock in the first period $\left(K_{1}\right)$ is exogenously given. The capital stock in the second period $\left(K_{2}\right)$ must satisfy the investment rule of the firm [equation (18)]. Note that because the economy is fiinancially open, the individuals, by the arbitrage condition [equation (9)], are indifferent between chanelling their savings domestically or abroad. This means that the government can choose $K_{2}$, and then $r$ and the pre-tax wages $\left(w_{1}\right.$ and $\left.w_{2}\right)$ are determined so as to clear the capital market and labor market in each period through equations (18), (16) and (17), respectively. This does not mean that the government actually chooses the stock of capital $\left(K_{2}\right)$ for the firm, or the pre-tax wage rates $\left(w_{1}\right.$ and $\left.w_{2}\right)$, or the domestic interest rate $(r)$. Rather $w_{1}, w_{2}$ and $r$ are determined by market clearance and the firm chooses $K_{2}$ so as to maximize its value. What we did is to determine $K_{2}, w_{1}, w_{2}$ and $r$ at levels which are compatible with firm-value maximization and market clearance in the presence of taxes.

To sum up, the government in a political-economy equilibrium chooses $C_{1}^{G}, C_{2}^{G}, R$, $w_{1}^{N}, w_{2}^{N}, T$ and $K_{2}$, so as to maximize the utility of the median voter [as given by equation (29)], subject to the economy-wide "budget" constraint, equation (26). Note that $C_{1}, C_{2}$, $L_{1}, L_{2}$ and $e^{*}$ in the latter constraint are replaced by the functions $C_{1}(\cdot), C_{2}(\cdot), L_{1}(\cdot), L_{2}(\cdot)$ and $e^{*}(\cdot)$, respectively. We can ignore the government budget constraint (20) by Walras Law.

Note that in this maximization, $K_{2}$ appears only in the economy-wide "budget" constraint, equation (26). Thus, the first-order condition for the political-economy equilibrium level of $K_{2}$ is given by: 


$$
1-R^{*} F_{K}\left(K_{2}, L_{2}\right)-R^{*}(1-\delta)=0 .
$$

Note that this choice does not depend on whether the median voter is skilled or unskilled.

Substituting the firm's investment rule, equation (18), and rearranging terms yield:

$$
1-\delta+F_{K}\left(K_{2}, L_{2}\right)=1+\left(1-\tau_{N}^{*}\right) r^{*} .
$$




\section{NOTES}

1. Evidently, if the tax is progressive, the payoff would be reduced proportionally more than the foregone-income cost.

2. These rates $\left(r\right.$ and $\left.r^{*}\right)$ hold in essence between periods one and two and we therefore assign no time subscript (one or two) to these rates.

3. Evidently in a non-stochastic set-up like ours, the country is either capital exporter or capital importer.

4. Note that even though $T$ may seem at first glance to be dependent on $\tau_{D}$ (through the discount factor $R$ ), we may nevertheless assume that these are two independent policy tools because the government can always change either $T_{1}$ and $T_{2}$ in order to keep $T$ constant when it changes $\tau_{D}$.

5. For notational simplicity, we assume that the net external assets are initially equal to zero, so that there is no initial external debt payment term in the current account. 


\section{References}

Diamond, Peter A., and James A. Mirrlees (1971). "Optimal Taxation and Public Production." American Economic Review (March and June).

Obstfeld, M., and Alan M. Taylor (2003). "Globalization and Capital Markets." In: Michael D. Bordo, Alan M. Taylor and Jeffrey G. Williamson, eds., Globalization in Historical Perspective. Chicago: University of Chicago Press.

Razin, Assaf and Efraim Sadka, with the cooperation of Chang Woon Nam (forthcoming). The Decline of the Welfare State: Demography and Globalization, MIT Press.

Razin, Assaf, Efraim Sadka and Phillip Swagel (2002). "The Aging Population and the Size of the Welfare State." Journal of Political Economy 110, 4 (August): 900-918.

Razin, Assaf, Efraim Sadka and Phillip Swagel (2004). "Capital Income Taxation under Majority Voting with Aging Population," Review of World Economics (Weltwirtschftliches Archiv) 140, 3. 
Table 1: Statutory Corporate Tax Rates in the Enlarged EU, 2003

\begin{tabular}{|l|l|}
\hline Country & Tax Rates (\%) \\
\hline \hline Austria & 34 \\
\hline Belgium & 34 \\
\hline Cyprus* $^{*}$ & 15 \\
\hline Czech Republic* $^{*}$ & 31 \\
\hline Denmark & 30 \\
\hline Estonia* & 0 \\
\hline Finland & 29 \\
\hline France & 33.3 \\
\hline Germany & 40 \\
\hline Greece & 35 \\
\hline Hungary* & 18 \\
\hline Ireland & 12.5 \\
\hline Italy & 34 \\
\hline Latvia* & 19 \\
\hline Lithuania* & 15 \\
\hline Luxembourg & 22 \\
\hline Malta* & 35 \\
\hline Netherlands & 34.5 \\
\hline Poland* & 27 \\
\hline Portugal & 30 \\
\hline Slovakia* & 25 \\
\hline Slovenia* & 25 \\
\hline Spain & 35 \\
\hline Sweden & 28 \\
\hline UK & 30 \\
\hline & entrants. \\
\hline
\end{tabular}




\section{Figure 1: The Optimal-tax stock of capital $\left(K_{2}\right)$}

Second-period consumption

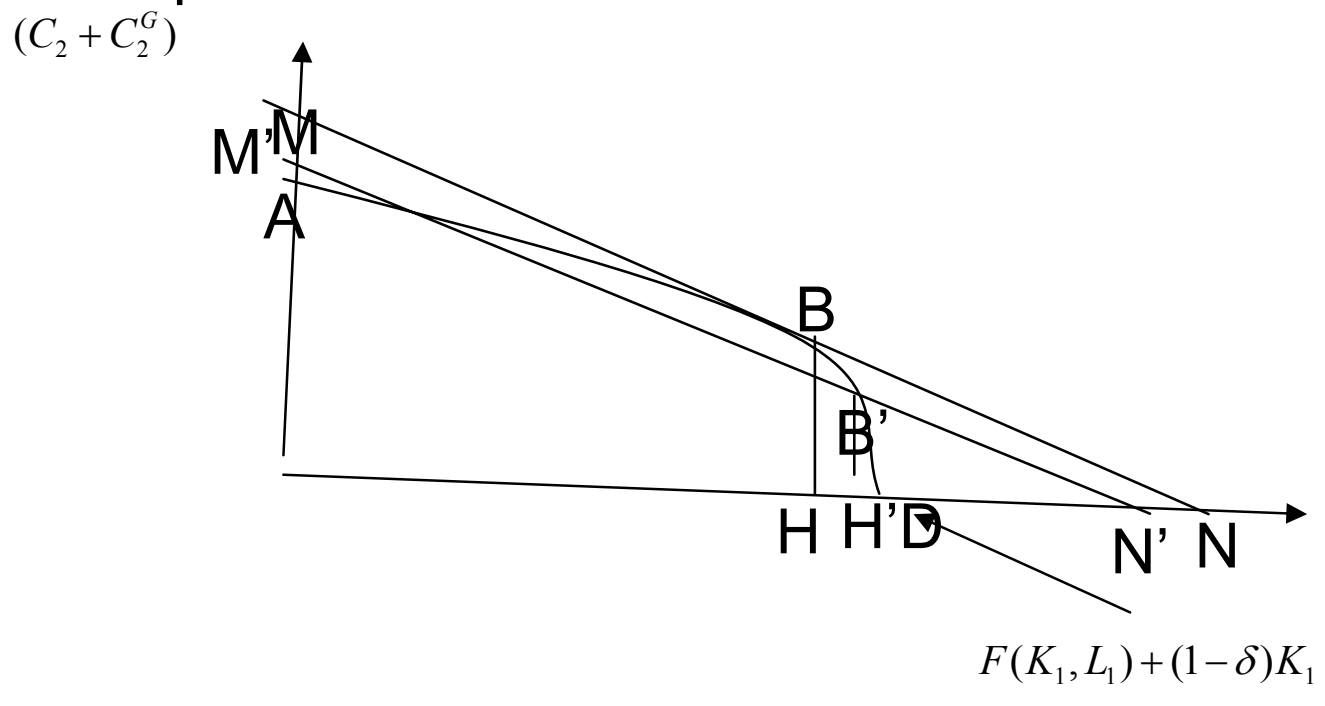

First-period consumption

$$
\left(C_{1}+C_{1}^{G}\right)
$$

